\title{
Does a surgical mask improve oxygenation in COVID-19 patients?
}

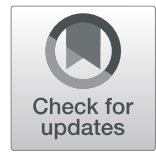

Yusuke Matsui, Tomonori Takazawa* ${ }^{*}$, Akihito Takemae and Shigeru Saito

To the Editor,

For anesthesiologists and operating room nurses, protection from coronavirus disease 2019 (COVID19) infection while on duty is currently a top priority. According to the recommendation issued by the Japanese Society of Anesthesiology in March 2020, following extubation at the end of general anesthesia, the patient should receive oxygen via an oxygen mask placed over a surgical mask [1]. The rationale for this recommendation is the inhibitory effect of the surgical mask on the spread of respiratory aerosols. Binks and colleagues recently investigated whether the fraction of inspired oxygen $\left(\mathrm{FiO}_{2}\right)$ was different when wearing surgical masks above and below the oxygen mask. They suggested that oxygen supply via the oxygen mask was not disturbed by simultaneous use of a surgical mask [2]. From a slightly different point of view, however, COVID-19 patients with severe hypoxia might require oxygen administration for a long time after extubation. We devised a method of delivering oxygen through a nasal cannula under a surgical mask to obtain maximum oxygenation while preventing aerosol dispersal (Fig. 1). We compared our method with the method recommended by Binks et al. in a patient with COVID-19 being treated at our intensive care unit.

The results are shown in Table 1. Partial pressure of oxygen in arterial blood $\left(\mathrm{PaO}_{2}\right)$ clearly decreased when changing from the nasal cannula to the oxygen mask, recovering once again when returning to the nasal cannula. In contrast, other indices, such as $\mathrm{pH}$, partial pressure of carbon dioxide in arterial blood $\left(\mathrm{PaCO}_{2}\right)$, base excess, and respiratory rate, remained almost unchanged. These results suggest that oxygen delivered via a nasal cannula worn under a surgical mask might prevent the spread of infection while simultaneously allowing maintenance of a high $\mathrm{PaO}_{2}$ in patients.

To verify why our method was advantageous for oxygenation, we decided to estimate inhaled oxygen concentration when oxygen was administered to a healthy subject. Due to technical difficulties, we compared oxygen levels in exhaled air rather than inhaled air: Exhaled oxygen concentration was 23\% with the oxygen mask, and 33\% with the nasal cannula (Supplemental Figure 1). Considering that oxygen consumption during these measurements was constant,

* Correspondence: takazawt@gunma-u.ac.jp

Intensive Care Unit, Gunma University Hospital, 3-39-15 Showa-machi, Maebashi, Gunma 371-8511, Japan

\section{Springer Open}

(c) The Author(s). 2021 Open Access This article is licensed under a Creative Commons Attribution 4.0 International License, which permits use, sharing, adaptation, distribution and reproduction in any medium or format, as long as you give appropriate credit to the original author(s) and the source, provide a link to the Creative Commons licence, and indicate if changes were made. The images or other third party material in this article are included in the article's Creative Commons licence, unless indicated otherwise in a credit line to the material. If material is not included in the article's Creative Commons licence and your intended use is not permitted by statutory regulation or exceeds the permitted use, you will need to obtain permission directly from the copyright holder. To view a copy of this licence, visit http://creativecommons.org/licenses/by/4.0/. 
A
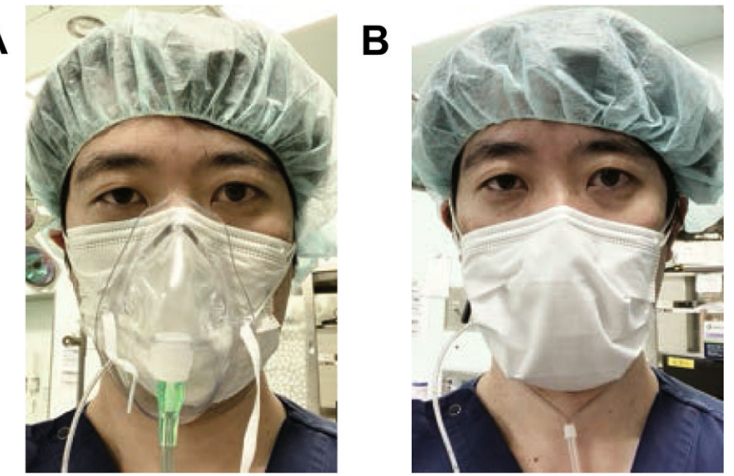

Fig. 1 The two different oxygen administration methods tested. Image showing wearing an oxygen mask above the surgical mask (a) and wearing a nasal cannula below the surgical mask (b)

the difference in exhaled oxygen concentration can be interpreted as a reflection of the difference in inhaled oxygen concentration.

A limitation of our report is that we do not know why our method resulted in an enhanced $\mathrm{FiO}_{2}$, leading to the higher $\mathrm{PaO}_{2}$. Although it is controversial whether the oxygen mask or nasal cannula is more advantageous for oxygenation $[3,4]$, wearing a surgical mask over the cannula improved oxygenation in COVID-19 patients in a study with high-flow nasal cannula treatment [5]. Details about the mechanism for the superiority of our method are unknown and need to be clarified.

We were able to obtain good oxygenation in a patient with COVID-19 by supplying oxygen via a nasal cannula used below a surgical mask. We need to investigate this method in other COVID-19 patients in the future. Additionally, this method could be applied to patients other than those with COVID-19.

Table 1 Results of blood gas analysis in the COVID-19 patient

\begin{tabular}{llll}
\hline Oxygen supply device & $\begin{array}{l}\text { Nasal } \\
\text { cannula }\end{array}$ & $\begin{array}{l}\text { Oxygen } \\
\text { mask }\end{array}$ & $\begin{array}{l}\text { Nasal } \\
\text { cannula }\end{array}$ \\
\hline Oxygen flow rate $(\mathrm{L} / \mathrm{min})$ & 4 & 4 & 4 \\
$\mathrm{pH}$ & 7.38 & 7.41 & 7.41 \\
$\mathrm{PaO}_{2}(\mathrm{mmHg})$ & 154 & 108 & 150 \\
$\mathrm{PaCO}_{2}(\mathrm{mmHg})$ & 36.1 & 32.9 & 32.6 \\
Base excess $(\mathrm{mmol} / \mathrm{L})$ & -3.5 & -3.4 & -3.8 \\
Respiratory rate $($ breaths/min) & 29 & 30 & 28 \\
\hline
\end{tabular}

We collected arterial blood samples and performed blood gas analysis when the patient wore a nasal cannula under the surgical mask and when the patient wore an oxygen mask over the surgical mask. Blood samples were taken between 15 and $60 \mathrm{~min}$ after the change in oxygen administration method, i.e., after the patient received oxygen for at least $15 \mathrm{~min}$ by the method being tested. This was to clarify that the results of blood gas analysis were due to the different methods of oxygen administration. Arterial blood was analyzed by a blood gas analyzer (ABL800 FLEX, Radiometer Medical ApS, Denmark). $\mathrm{PaO}_{2}$, partial pressure of oxygen in arterial blood; $\mathrm{PaCO}_{2}$, partial pressure of carbon dioxide in arterial blood

\section{Abbreviations}

$\mathrm{FiO}_{2}$ : Fraction of inspired oxygen; COVID-19: Coronavirus disease 2019;

$\mathrm{PaO}_{2}$ : Partial pressure of oxygen in arterial blood; $\mathrm{PaCO}_{2}$ : Partial pressure of carbon dioxide in arterial blood

\section{Supplementary Information}

The online version contains supplementary material available at https://doi. org/10.1186/s40981-021-00439-7.

Additional file 1: Supplemental Figure 1. Results of gas analysis in a healthy male volunteer. The figures show the results of gas analysis when $4 \mathrm{~L} /$ min of oxygen was administered via an oxygen mask worn over a surgical mask (A) and via a nasal cannula worn below a surgical mask (B). The subject was instructed to hold the tip of the gas sampling line in his mouth. He was asked to breathe at a respiratory rate of about 15-17 breaths/min, and when his $\mathrm{EtCO}_{2}$ stabilized at about $40 \mathrm{mmHg}$, the oxygen concentration in exhaled air was assessed and compared between the two methods. A multi-gas analysis unit (GF-320R, Nihon Kohden Corporation, Tokyo) was used for the measurement. RR, respiratory rate; $\mathrm{O}_{2}-\mathrm{E}$, oxygen concentration in exhaled air; $\mathrm{O}_{2}-\mathrm{l}$, oxygen concentration in inhaled air; $\mathrm{CO}_{2}-\mathrm{E}$, carbon dioxide concentration in exhaled air; $\mathrm{CO}_{2}-\mathrm{I}$, carbon dioxide concentration in inhaled air.

\section{Acknowledgements}

Editorial support, in the form of medical writing based on the authors' detailed directions, collating author comments, copy editing, fact checking, and referencing, was provided by the professional editing company, Forte Science Communications.

\section{Authors' contributions}

YM contributed to data collection and manuscript writing. TT contributed to manuscript writing and critical review of the manuscript. AT contributed to data collection. SS contributed to report supervision and interpretation. The authors read and approved the final manuscript.

\section{Funding}

Preparation of this manuscript was supported by the Japan Society for the Promotion of Science KAKENHI Grant Number 20K17828.

Availability of data and materials

Data relevant to this letter are not available for public access because of patient privacy concerns, but are available from the corresponding author on reasonable request.

\section{Declarations}

Ethics approval and consent to participate

Written informed consent was obtained from the healthy volunteer for participation in the study and publication of the results and accompanying images.

\section{Consent for publication}

Written informed consent for publication of this report was obtained from the patient.

\section{Competing interests}

The authors declare that they have no competing interests.

Received: 5 February 2021 Revised: 9 March 2021 Accepted: 6 April 2021 Published online: 14 April 2021

\section{References}

1. Japanese Society of Anesthesiologists. Our response to coronavirus disease 2019 (COVID-19). 2020. https://anesth.or.jp/img/upload/ckeditor/files/2004_ 07 01.pdf Accessed 5 Mar 2021.

2. Binks AC, Parkinson SM, Sabbouh V. Oxygen: under or over a surgical facemask for COVID-19 patients? Anaesthesia. 2020;75(12):1691-2. https:// doi.org/10.1111/anae.15166. 
3. Ayhan H, Iyigun E, Tastan S, Orhan ME, Ozturk E. Comparison of two different oxygen delivery methods in the early postoperative period: randomized trial. J Adv Nurs. 2009;65(6):1237-47. https://doi.org/10.1111/j.13 65-2648.2009.04984.x.

4. Stausholm K, Rosenberg-Adamsen S, Skriver M, Kehlet H, Rosenberg J. Comparison of three devices for oxygen administration in the late postoperative period. Br J Anaesth. 1995;74(5):607-9. https://doi.org/10.1 093/bja/74.5.607.

5. Montiel V, Robert A, Robert A, Nabaoui A, Marie T, Mestre NM, et al. Surgical mask on top of high-flow nasal cannula improves oxygenation in critically ill COVID-19 patients with hypoxemic respiratory failure. Ann Intensive Care. 2020;10(1):125. https://doi.org/10.1186/s13613-020-00744-x.

\section{Publisher's Note}

Springer Nature remains neutral with regard to jurisdictional claims in published maps and institutional affiliations.

\section{Submit your manuscript to a SpringerOpen ${ }^{\odot}$ journal and benefit from:}

- Convenient online submission

- Rigorous peer review

- Open access: articles freely available online

High visibility within the field

- Retaining the copyright to your article

Submit your next manuscript at $\boldsymbol{\sim}$ springeropen.com 